Proc. Estonian Acad. Sci. Biol. Ecol., 2004, 53, 2, 116-143

\title{
History of ecosystem studies of the Gulf of Riga (Baltic Sea)
}

\author{
Henn Ojaveer ${ }^{\mathrm{a}^{*}}$ and Andris Andrushaitis ${ }^{\mathrm{b}}$ \\ ${ }^{\text {a }}$ Estonian Marine Institute, University of Tartu, Mäealuse 10a, 12618 Tallinn, Estonia \\ ${ }^{\mathrm{b}}$ Institute of Aquatic Ecology, University of Latvia, 3 Miera Street, LV 2169 Salaspils, Latvia; \\ andris@hydro.edu.lv
}

Received 16 June 2003, in revised form 22 March 2004

\begin{abstract}
Compared to some abiotic data, observations on biotic components of the ecosystem of the Gulf of Riga have about two centuries shorter history: the first known notes on flora and fauna date back to the mid-18th century whereas almost continuous ice breakdown data in the Riga harbour exist since the first half of the 16th century. The first scientific cruise, the Russian Baltic expedition, was carried out in 1908-09. Then the first data on planktonic organisms were obtained. Systematic investigations were performed independently in the northern and southern parts of the gulf by the bordering countries since the mid-1920s. However, until World War II most studies were descriptive. In the late 1940s comprehensive ecosystem studies were commenced. Strong emphasis was put on commercial fish stocks with causative and predictive approach. Although some previously initiated studies have been continued or expanded, some long-term datasets were broken in the second half of the 1990s.
\end{abstract}

Key words: Gulf of Riga, abiotic and biotic environment, research history.

\section{INTRODUCTION}

Exploitation of biological resources of the Gulf of Riga (GoR) by inhabitants of areas of present Estonia and Latvia has an incomparably longer history than existing archival documents while records on fish catches or scientific observations have been accumulated relatively recently. Moreover, our knowledge on the development of the GoR ecosystem even during the relatively recent times (until the 20th century) is far from complete. The currently ongoing interdisciplinary investigations within the History of Marine Animal Population's (HMAP) project, involving both historians and ecologists, allow us to expect new evidences on historical developments of fisheries in the GoR and adjacent areas. Further, the importance of long time series for tracing the dependence of biological processes

\footnotetext{
* Corresponding author, henn@pc.parnu.ee
} 
on the cosmic and climatic influences is obvious. Therefore, it can be predicted that in the future the efforts to increase the length of the biological time series including the data from previous studies will deserve more attention than at present.

A number of scientific overview contributions have already been published (Laganovska \& Kachalova, 1990; Ojaveer, 1995; Ojaveer et al., 2001; Vitinsh et al., 2001). These cover to a lesser or greater extent the historical aspect of studies of the GoR. Except the GoR ecosystem monograph (Ojaveer, 1995), these publications are arranged by historical time periods where institutional and human components and their contributions to the development of marine research are in the focus. Another approach has been used by Andrushaitis (1987), who performed ecological zonation of the GoR on the basis of a set of hydrochemical (salinity, oxygen, oxidation rate, concentration of nutrients and labile organic matter) and hydrobiological (bacterio-, phyto-, and zooplankton and zoobenthos) data from 1972-82.

The aim of the current paper is to give an overview of the development of ecosystem studies of the GoR with an emphasis on various structural/functional components of the ecosystem. Listing of all available publications was not our aim. Still, by giving references to more important sources, we wish to direct today's international scientific community to rich, but perhaps less known data sources collected by scientists of earlier times. In addition, institutional development is briefly touched and examples of more important comprehensive investigations are presented.

\section{INSTITUTIONAL DEVELOPMENT}

In the 1920s studies in the GoR ecosystem were started by scientists of the University of Tartu and the University of Latvia (Hydrobiological Laboratory). The general background of these investigations was agreed in 1921 when Estonian, Finnish, and Latvian scientists met in the Estonian Ministry of Agriculture in Tallinn for discussions on initiating systematic investigations in hydrography, plankton, and marine fishes (Ojaveer et al., 2001). During World War II studies of the sea were disrupted. After World War II the scientific work was resumed in the All-Union Research Institute of Marine Fisheries and Oceanography (VNIRO). In 1944 the Estonian Department of the VNIRO and in 1945 the respective Latvian Department were founded. Mainly applied studies directed towards the estimation of the size and condition of fish resources and possibilities of their exploitation were developed at both departments. In 1957 the Estonian Department of VNIRO was reorganized and during the years 1958-62, the Laboratory of Marine Ichthyology was subordinated to the Academy of Sciences of the Estonian SSR. In 1959 the Latvian Department of VNIRO became Fisheries Research Institute and in 1962, the Baltic Fisheries Research Institute (BaltNIIRH). In 1963 the Estonian Laboratory of Marine Ichthyology (later renamed the Tallinn Department) was subordinated to the BaltNIIRH (up to 1991). Marine investigations were also performed within the systems of hydrometeorological services of both republics (both subordinated to the All-Union Hydrometeoro- 
logical Board) as well as within Academies of Sciences: in Estonia by the Institute of Thermophysics and Electrophysics (1972-90), the Institute of Zoology and Botany (1974-90), and the Institute of Ecology and Marine Research (1990-92); in Latvia by the Institute of Biology (1964-95). Presently, marine investigations in both Estonia and Latvia are carried out by university institutes: Estonian Marine Institute at the University of Tartu (created in 1992, university institute since 2001), the Institute of Aquatic Ecology of the University of Latvia (since 1995), and the Marine Systems Institute of Tallinn Technical University (since 2002). In Latvia the Latvian Fisheries Research Institute (since 1991) carries out fisheries research as well as some marine hydrological studies.

\section{ABIOTIC ENVIRONMENT}

\section{Hydrology}

Due to practical considerations (maritime transport) ice observations have the longest history. By including partly model estimates, ice formation and breakdown data in Riga harbour are available since 1529 (Jevrejeva, 2001). With some sporadic observations in the mid-1800s, data on the formation and breakdown of ice in the GoR itself are, in general, available since the mid-1890s (Mardiste, 1995). In addition, sea ice observations were carried out daily mostly at lighthouses: the amount of ice, ice types, ice movement, shipping possibilities, and ice and snow thickness were estimated. Since 1923/24 the data were published as special reports of the Commission of the Investigation of Estonian Waterbodies at the University of Tartu (Frisch, 1924).

First observations on water level fluctuations in Pärnu harbour date back to 1806 (Anon., 1807, cited in Mardiste, 1995) and in Riga to 1841 (Stakle, 1931). Later, during the second half of the 19th century, several papers on water level fluctuations in the northern GoR were published (e.g., Sass, 1865). Regular water level measurements at Kolkasrags were started in 1884 (Stakle, 1931). The first information on water currents date back to 1871 and water temperature observations started in the late 19th century (Anon., 1871; Mardiste, 1995).

Selected hydrological parameters were also measured during the first Baltic Russian expedition (1908-09) and comprehensive interdisciplinary cruises in the 1920s and 1930s (see below).

In 1932-40 daily measurements of currents at the entrance of the Irbe Strait (Ovishi lightship) were performed. This rich dataset served for the first estimates of water exchange between the GoR and the Baltic Proper (Pastors, 1954). Extensive systematic observations during the period 1947-90 were performed by the Hydrometeorological Service (collected data published in classified issues, e.g., TGM-3M, 1963-70; Arsenyeva, 1972). Based on these data, currents in the Irbe and Muhu straits were described (Mardiste, 1964; Baranov, 1970), main regularities in seasonal and annual changes of water temperature (e.g., Pastors, 1969; Matisone, 1974a; Berzinsh, 1979), salinity (Auninsh, 1966; Matisone, 1974b; Berzinsh, 1980), and transparency (Zakharchenko, 1962) were studied, water 
and heat balance was calculated (Pastors, 1967), and the formation of oxygen deficiency zones in the bottom water was explained (Zakharchenko, 1982). Finally, thorough analysis of long-term dynamics of these oceanographic parameters (1960s-90s) was given by Berzinsh (1995). In the 1990s, within the frame of an international the Gulf of Riga project new extensive field data on meteorology and hydrography were collected and modelling efforts were made (e.g., Toompuu \& Elken, 1995; Suursaar \& Astok, 1996; Berzinsh et al., 2001).

\section{Hydrochemistry}

Although concentrations of several salts in seawater were determined already in 1844 (Goebel, 1845) and the salinity calculations (in \%o) of earlier measurements were performed by Schweder (1882), the first scientific survey involving the measuring of some hydrochemical parameters (water salinity and oxygen content) was carried out during the Russian Baltic expedition in 1908-09. Regular annual hydrochemical observations were made in the northern part of the GoR in 192439 (Frisch \& Riikoja, 1925, 1928, 1929, 1931; Kirde, 1940). Locations of stations sampled during these cruises are shown in Fig. 1 and an example of the abiotic data recording format in Fig. 2. The cruise details along with the list of variables

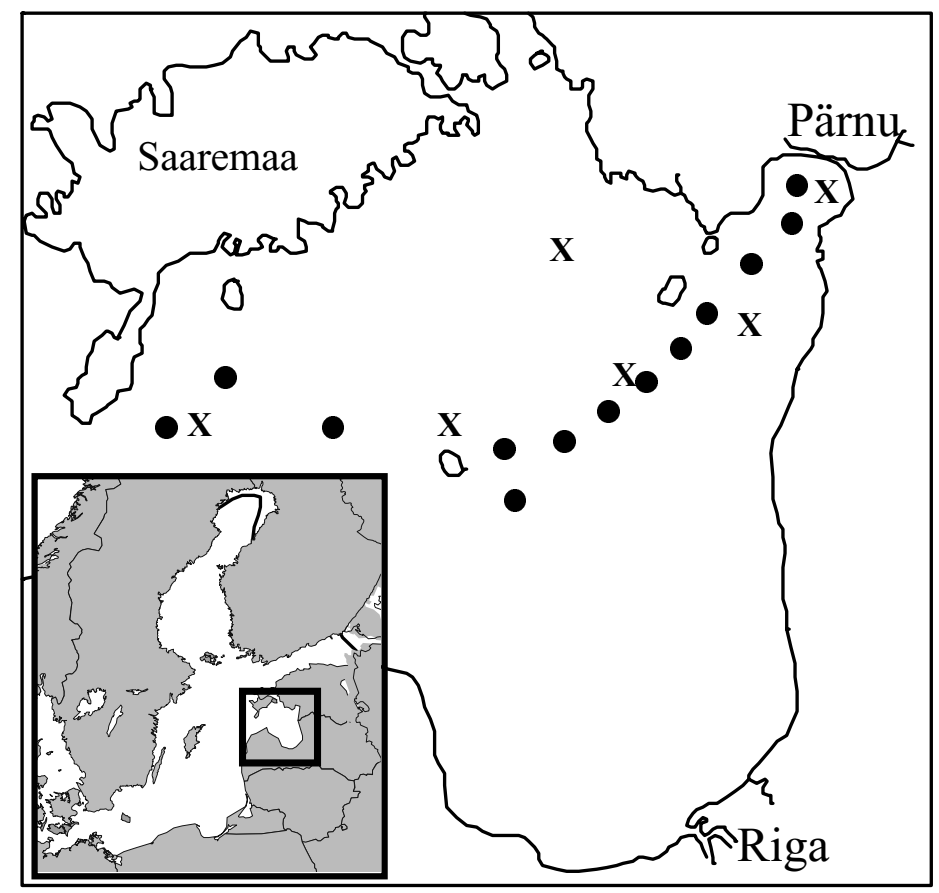

Fig. 1. Location of stations of Estonian terminal cruises in the 1920s and 1930s (crosses) and comprehensive investigations on the environment and fish in the 1990s (filled circles). 
Tabelle № 2 .

Temperatur, Salzgehalt und meteorologische Beobachtungen an den Stationen. 1927.

\begin{tabular}{|c|c|c|c|c|c|c|c|c|c|c|c|}
\hline $\mathrm{m}$ & $t^{0}$ & & $\sigma_{\mathrm{t}}$ & $\mathrm{m}$ & $\mathrm{t}^{0}$ & 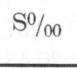 & $\sigma_{\mathrm{t}}$ & $\mathrm{m}$ & $t^{0}$ & $0 \%$ & $\sigma_{\mathrm{t}}$ \\
\hline \multicolumn{4}{|c|}{$\begin{array}{l}P .1 \mathbf{A} ; 192718 \\
\varphi=59^{0} 33^{\prime}, \lambda=2\end{array}$} & \multicolumn{4}{|c|}{$\begin{array}{l}\text { P. 3; } 192719 \text { VII, } 9 \mathrm{~h} 20 \mathrm{~m} \\
\varphi=59^{0} 52^{\prime}, \lambda=26^{0} 17^{\prime}, 80 \mathrm{~m}\end{array}$} & 80 & 0 & & \\
\hline $\begin{array}{r}0 \\
5 \\
10\end{array}$ & \begin{tabular}{|r}
21.5 \\
12.4 \\
4.6
\end{tabular} & 0 & .23 & 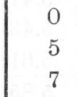 & 0. & & $\begin{array}{l}2 \\
6 \\
6\end{array}$ & \multicolumn{4}{|c|}{$\begin{array}{c}\text { ESE } 4.0, \mathrm{~T}=22.80, \mathrm{R}=68 \%, \\
\mathrm{~S}=1, \mathrm{~B}=4 / 10 .\end{array}$} \\
\hline 15 & & & & & & & & \multirow{2}{*}{\multicolumn{4}{|c|}{$\begin{array}{l}\text { P. 5 ; } 192720 \text { VII, } 7 \mathrm{~h} 45^{\mathrm{m}} \\
\varphi=59^{0} 43^{\prime}, \lambda=25^{\circ} 01^{\prime}, 5,85 \mathrm{~m} .\end{array}$}} \\
\hline 20 & & & & & & & & & & & \\
\hline 30 & 2.45 & - & - & & & & & & & & 1 \\
\hline \multirow{3}{*}{\multicolumn{4}{|c|}{$\begin{array}{c}\text { NE } 2.0, T=23.2^{0}, R=87 \% \\
\quad S=1, B=3 / 10\end{array}$}} & 60 & 2.0 & 7. & 5. & o & & 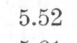 & 3.6 \\
\hline & & & & 80 & 2.97 & 7.7 & 6.2 & & & & 4.3 \\
\hline & & & & \multicolumn{4}{|c|}{$\begin{array}{c}\mathrm{SSE} 3.7, \mathrm{~T}=22.0^{0}, \mathrm{R}=84 \% \\
\mathrm{~S}=1, \mathrm{~B}=2 / 10^{0}\end{array}$} & & & & \\
\hline \multirow{2}{*}{\multicolumn{4}{|c|}{$\begin{array}{l}1 ; 192718 \text { VII, } 15 \mathrm{~h} 20 \mathrm{~m} \\
=59^{0} 38^{\prime}, \lambda=27^{0} 29^{\prime}, 35 \mathrm{~m}\end{array}$}} & & & & & & 3.98 & 6.65 & 5.3 \\
\hline & & & & \multirow{2}{*}{\multicolumn{4}{|c|}{$\begin{array}{l}\text { P. 4; } 192719 \text { VII, } 13^{\mathrm{h}} 15^{\mathrm{m}} \\
\varphi=59^{0} 50^{\prime}, \lambda=25^{0} 37^{\prime}, 70 \mathrm{~m}\end{array}$}} & 60 & 2.48 & 7.11 & 5.72 \\
\hline 0 & 22.25 & & 0.42 & & & & & & 6 & 7 & 7.4 \\
\hline $\begin{array}{l}3 \\
5\end{array}$ & $\begin{array}{l}2 \\
1\end{array}$ & & $\begin{array}{l}0 \\
2\end{array}$ & & & & & \multirow{2}{*}{\multicolumn{4}{|c|}{$\begin{array}{c}-0.0, \mathrm{~T}=18,3^{0}, \mathrm{R}=77 \% \\
\mathrm{~S}=1, \mathrm{~B}=7 / 10^{\circ}\end{array}$}} \\
\hline 11 & & & 3 & 2 & & & & & & & \\
\hline 5 & & & & 5 & & & & \multicolumn{4}{|c|}{$\begin{array}{l}\text { P. } 6 \text { A; } 192720 \text { VII, } 10^{\mathrm{h}} 30 \mathrm{~m} \\
\varphi=59^{0} 36^{\prime}, \lambda=24^{0} 41^{\prime}, 80 \mathrm{~m} .\end{array}$} \\
\hline 25 & & & & 1 & & & & 0 & & & 3.0 \\
\hline 35 & & & & 20 & 3. & & & & & & 3.4 \\
\hline \multirow{2}{*}{\multicolumn{4}{|c|}{$\begin{array}{c}\text { NE } 4.0, T=23.5^{0}, \mathrm{R}=80 \% \\
\quad \mathrm{~S}=1, \mathrm{~B}=4 / 10\end{array}$}} & 30 & & & & 5 & & & 3.9 \\
\hline & & & & 40 & 2.1 & 6.6 & 53 & 7 & & & .7 \\
\hline \multirow{2}{*}{\multicolumn{4}{|c|}{$\begin{array}{l}\text { P. } 2 ; 192718 \text { VII, } 18 \mathrm{~h} 30 \mathrm{~m} \\
\varphi=59^{0} 47^{\prime}, \lambda=27^{0} 05^{\prime}, 64 \mathrm{~m} .\end{array}$}} & & & & & 20 & & & \\
\hline & & & & \multirow{2}{*}{\multicolumn{4}{|c|}{$\begin{array}{c}\text { SE } 2.3, \mathrm{~T}=22.2^{0}, \mathrm{R}=76 \% \\
\mathrm{~S}=1, \mathrm{~B}=2 / 10 .\end{array}$}} & & & 6.64 & 5.3 \\
\hline 0 & & & & & & & & bu & & & \\
\hline 5 & & & & \multirow{2}{*}{\multicolumn{4}{|c|}{$\mid \begin{array}{l}\text { P. 5 A ; } 192719 \text { VlI, } 16^{\mathrm{h}} 00 \mathrm{~m} \\
\varphi=59^{0} 41^{\prime}, 5, \lambda=25^{0} 34^{\prime}, 5,85 \mathrm{~m} .\end{array}$}} & 75 & 3.30 & 9.52 & 7.65 \\
\hline 7 & & & & & & & & \multirow{2}{*}{\multicolumn{4}{|c|}{$\begin{array}{c}-0.0, \mathrm{~T}=19.6^{0}, \mathrm{R}=88 \%, \\
\mathrm{~S}=0, \mathrm{~B}=7 / 10 .\end{array}$}} \\
\hline 10 & & & & & & & & & & & \\
\hline & & & & 3 & & & & \multirow{2}{*}{\multicolumn{4}{|c|}{$\begin{array}{l}\text { P. 6; } 192722 \text { VII } 11^{\mathrm{h}} 50^{\mathrm{m}} \\
\varphi=59^{0} 36^{\prime}, 5, \lambda=24^{0} 21^{\prime}, 85 \mathrm{~m} .\end{array}$}} \\
\hline 3 & & & & & & & & & & & \\
\hline & & & & & & & & 0 & & & 2. \\
\hline 00 & 2.45 & 6.83 & 5.5 & & & & & & & & 2.7 \\
\hline \multirow{2}{*}{\multicolumn{4}{|c|}{$\begin{array}{c}\text { BSE } 4.0, T=25.0^{0}, \mathrm{R}=81 \% \\
\mathrm{~S}=2, \mathrm{~B}=9 / 10^{\circ}\end{array}$}} & & & & & & & & \\
\hline & & & & & & & & 30 & 6.51 & 6.83 & 5.39 \\
\hline
\end{tabular}

Fig. 2. An example of the datasheet for the recording of some abiotic measurements during the Estonian terminal cruises in the 1920s (from Frisch \& Riikoja, 1929). 
determined are given in the section 'Examples of complex interdisciplinary cruises' below. Data on water salinity of the southern GoR are available from the same time (Strand \& Ozolins, 1929-36; Strand, 1940; Berzins, 1942). Also the first report on oxygen concentrations at different depths refers to 1924 (Mayer, 1926). In 1928/29 these parameters were supplemented with water alkalinity (Putnins, 1930). Nutrient analysis $\left(\mathrm{NH}_{4}-\mathrm{N}, \mathrm{NO}_{2-3}-\mathrm{N}, \mathrm{PO}_{4}-\mathrm{P}\right)$ were performed on water samples collected during Latvian terminal cruises in October 1932 and 1933, and April 1934 (Fig. 3; Zarins \& Ozolins, 1935). The Latvian Hydrometeorological Service restarted regular hydrochemical observations in 1957 and the Estonian Hydrometeorological Service in 1968. Data on the concentrations of nutrients and selected pollutants $(\mathrm{Cu}$, detergents, phenols) collected were published in marine hydrochemical bulletins (e.g., Fridman, 1969) issued 2 to 3 times a year and from 1984, in annual datasets on marine water quality of the Latvian SSR (e.g., Berg, 1985). Analyses of these datasets were performed by Auninsh $(1961,1965)$ and later by Laznik and co-workers (Laznik et al., 1988). In addition, extensive data were collected by the BaltNIIRH since the 1960s (Yurkovskij et al., 1977).

Salinity and the oxygen concentration regime (together with oxygen consumption rates) and factors and the mechanisms responsible for the corresponding dynamics were studied together with hydrological parameters during the period 1963-90. The dynamics in the rate of oxygen consumption and estimations on the anthropogenic load were presented by Berzinsh (1995).

Matisone \& Trautmanis (1982) distinguished three periods in the hydrochemical studies since the 1960s. The first period covering 1964-66 includes the years when the dilution impact of riverine discharge on the water masses in the southern GoR was investigated. The second period from 1968 to 1972 covers determination of the main sources of pollution in the southern GoR aimed at taking measures for better use and protection of the basin. The third period started in 1973 when the regularity of seasonal dynamics, salinity, thermal conditions, oxidation rate, and nutrients were determined. Long-term variations in the nutrient system of the GoR have been reported regularly by HELCOM in Periodic Assessments (e.g., Yurkovskis \& Mazmachs, 1996).

The hydrochemical regime of the relatively isolated Pärnu Bay (seasonal, vertical and horizontal variability, long-term trends of $\mathrm{O}_{2}, \mathrm{PO}_{4}, \mathrm{P}_{\text {tot }}, \mathrm{O}_{2}, \mathrm{NO}_{3}, \mathrm{SiO}_{4}$, and $\mathrm{pH})$ has been almost continuously studied in several stations since 1968 and recently summarized by Suursaar \& Tenson (1998).

Studies on heavy metals started in 1997 and have received since then substantial attention. Concentrations of heavy metals have been investigated in the water column, sediments, and biota at several trophic levels (macroalgae, plankton, benthic invertebrates, fish) (Kulikova, 1995; Seisuma \& Legzdina, 1995; Seisuma et al., 1998). The effect of heavy metals on plankton has been followed both in laboratory experiments (Andrushaitis \& Boikova, 1982; Balode, 1982) and in mesocosm enclosures (Seisuma et al., 1986). 


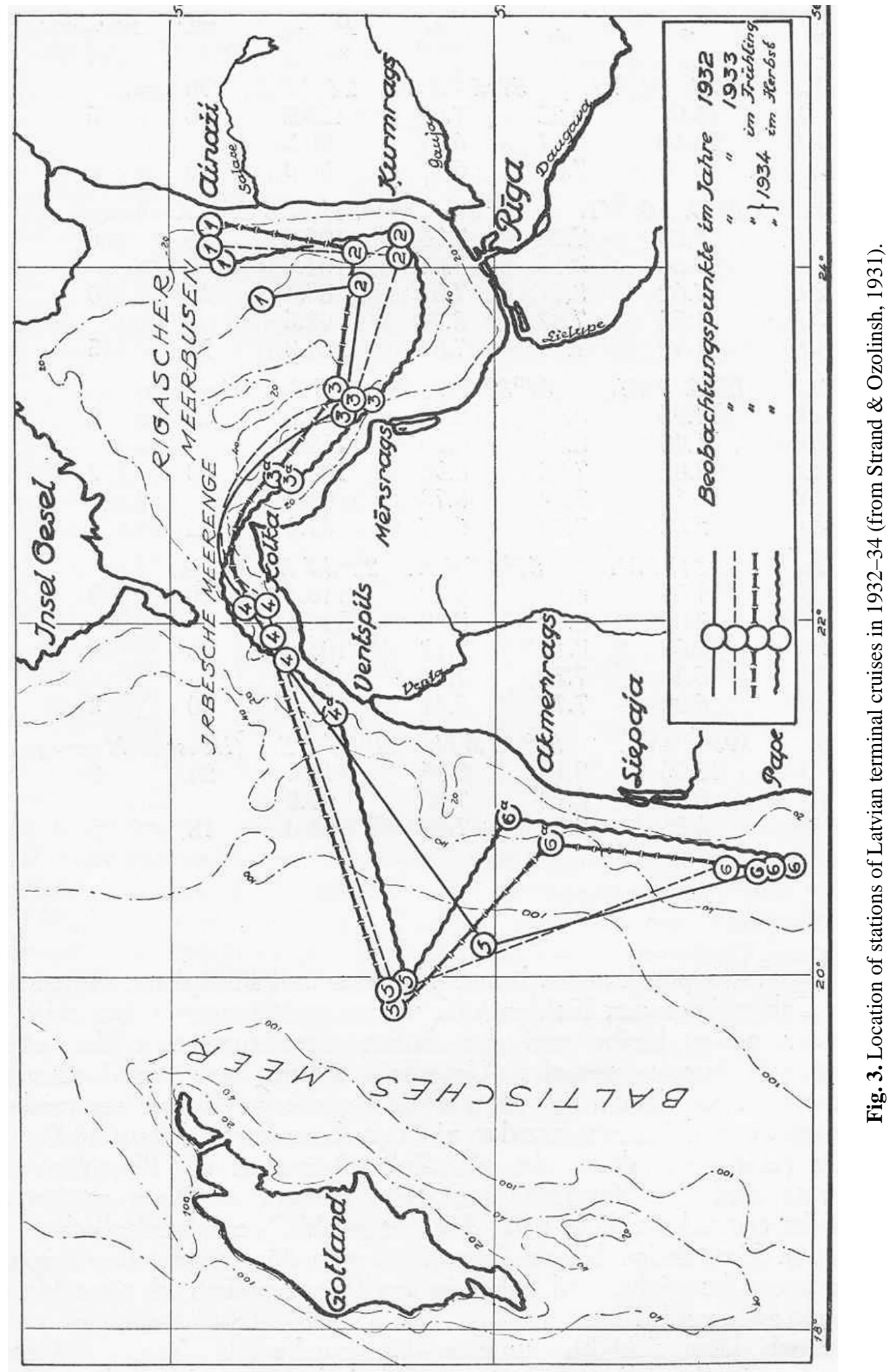




\section{BIOTIC ENVIRONMENT}

\section{Phytoplankton and primary production}

First data on phytoplankton were obtained during the Russian Baltic expedition in 1908-09. In these samples, 13 taxa were identified. Amongst the species those belonging to Aphanizomenon, Nodularia, and Anabaena dominated (Krabbi, 1913). In the 1920s and 1930s mainly the spatial distribution and species composition of phytoplankton (as well as zooplankton) were studied during the complex investigations both in the southern and northern parts of the GoR. Taxonomic and quantitative (by abundance categories) distribution of phytoplankton on horizontal and vertical scales (by different water layers) in the northern GoR in 1923-30 was regularly published (Frisch \& Riikoja, 1925, 1928, 1929, 1931). Publications on plankton in the southern part of the GoR appeared much more sporadically, although they present thorough analysis of different aspects of phytoplankton (and zooplankton) biology and therefore are frequently quoted by later authors. Thus, Rapaport (1929) followed seasonal development of net phytoplankton on the basis of samples collected from surface at 10 stations during monthly samplings conducted throughout the year. Berzins (1932) presents data collected during only one spring cruise in May 1928, giving insight into horizontal and vertical distribution of most abundant phytoplankton species and even speculating on diel vertical migration of the dinoflagellate Gonyaulax catenata. A floristic description of coastal algae (both planktonic and benthic) was given by Skuja (1924). Comprehensive studies started during the late 1940s and were published in the 1950s by Nikolaev $(1950,1957)$ and Nikolaev \& Krievs (1957). They determined species composition, studied seasonal, vertical, and horizontal distribution, estimated biomass (called "productivity" by these authors), and defined biological seasons according to phytoplankton data. Nikolaev (1950) differentiated three ecological complexes: marine euryhaline cold-water complex of arctic origin, marine euryhaline complex of boreal origin, and brackish-water and moderately warm water complex of freshwater origin. In the 1960s species composition, seasonal, vertical, and regional distribution in relation to abiotic environment in the pelagial was studied further (e.g., Rudzroga, 1974a, b; Kalveka, 1983).

Phytoplankton studies in the northeastern part of the basin, Pärnu Bay, started in 1964. These routine investigations were initially mostly directed towards taxonomic identification and patterns of seasonal succession of phytoplankton communities, but later seasonal dynamics of primary production and chlorophyll $a$ concentrations and observations on phytoplankton blooms were added. The total species list, along with other important aspects of phytoplankton development in Pärnu Bay, was summarized by Tenson (1995).

Since the early 1970s, phytoplankton pigments have been routinely used as an approximation of the autotrophic biomass (Yurkovskij \& Bramane, 1977). Based on these long-term (1972-91) data Jansone (1995) reported on almost two-fold increase of summer chlorophyll $a$ concentrations in the GoR between 1978 and 
1986. Phytoplankton development in relation to nutrients in the water was studied in the 1980s (Balode \& Tomsone, 1984). Using the long-term monitoring data (1972-95), Yurkovskis et al. (1999) related changes in the phytoplankton community to the restructured nutrient pool. Both phytoplankton and chlorophyll $a$ data from the GoR are being reported in HELCOM Assessments of the state of the marine environment of the Baltic Sea (e.g., Jansone, 1996; Kalveka, 1996).

First measurements of phytoplankton primary production in the GoR were performed in the early 1960s (Suschenya, 1961; Tenson, 1995). These data were later supplemented by seasonal measurements performed in 1969-70 (Zute, 1973), investigations on the effect of various factors on photosynthesis carried out in 1978 (Tenson, 1995), and photosynthesis measurements under the ice (Tenson \& Kaup, 1978). Andrushaitis et al. (1990) measured plankton primary production as well as plankton community respiration, sedimentation, and benthic respiration throughout the annual cycle of 1989. The balance of organic carbon of the entire basin was established on the basis of these data. Since that time plankton primary productivity has been determined routinely (e.g., Wasmund et al., 2001). Processoriented studies, both in field and laboratory conditions, were carried out in the 1990s when the influence of several abiotic factors (wind, solar radiation, nutrients) on primary production and respiration was estimated (Olesen et al., 1999; Tamminen \& Seppälä, 1999; Yurkovskis et al., 1999).

\section{Phytobenthos}

First documented evidence on the occurrence of phytobenthos in the basin dates back to 1778 when the bladder wrack Fucus vesiculosus was mentioned (Fischer, 1778). Before the 20th century, several qualitative studies were carried out (for review see Martin, 2000). First large-scale studies, but still on qualitative basis, were conducted by Skuja (1924), who identified at the south and west coasts of the basin over 50 phytobenthos species. After the World War II, in the late 1950s, the period of quantitative studies began. The first results of investigations of this kind were obtained in Pärnu Bay (Pullisaar, 1961) and by using SCUBA divers in the northern GoR (Trei, 1976). In order to describe the littoral vegetation, quantitative investigations were also started in the southern GoR in the 1960s (Kumsare et al., 1974). A major study that covered altogether $230 \mathrm{~km}$ and was of essential interest in terms of quantitative estimation of algal communities at larger scale, and on phytobenthic communities at the western and eastern coasts was published by Kalnozols (1973).

The best-studied region in the GoR in terms of long-term changes is Pärnu Bay, where respective studies began already in 1959 and were systematically continued in the following decades (Kukk, 1995). A detailed wide-scale study on phytobenthos and associated animal communities and evaluation of the present status in comparison to earlier investigations was carried out in the mid-1990s 
(Kautsky et al., 1999). When analysing causative relationships, Martin (2000) searched factors responsible for shaping the phytobenthic communities amongst several environmental factors such as depth, availability and type of the substrate, light conditions, sedimentation processes, wave activity, and also a combination of these factors. Recently attention has been paid to interactions between phyto- and zoobenthic communities. These studies deal with relating the variability in macrozoobenthos communities to the biomass structure of phytobenthos (Orav et al., 2000), changes in food and habitat preference of benthic invertebrates in relation to altered macroalgal community (Kotta et al., 2000), and decomposition of macroalgae by benthic invertebrates (Paalme et al., 2002).

\section{Microorganisms}

Microbiological investigations were developed in the following two major directions: (1) marine bacteria that may affect human health, and (2) transformation and destruction processes of organic substances (including various organic pollutants). Studies in microorganisms started in the littoral part in the southern GoR in 1965-66 with emphasis on the relationship between the abundance of bacterioplankton and the concentration of inorganic nutrients and organic substances discharged into the GoR (Kochish et al., 1967).

In the late 1960s and the early 1970s studies of horizontal and vertical distribution and seasonal dynamics of bacterioplankton (incl. saprophytic bacteria) in the littoral zone of the southern basin were started (Marcinkevicha \& Zute, 1974). In the early 1970s studies in oil-oxidizing bacteria were initiated (Marcinkevicha, 1974). These were continued and expanded throughout the 1980s (for review see Platpira, 1985). In the 1970s and 1980s investigations on various aspects of microbial ecology (spatio-temporal distribution of the abundance and biomass of various physiological groups, productivity, annual changes in relation to abiotic environment) expanded over the whole GoR (e.g., Apine \& Botva, 1982; Marcinkevicha, 1984; Platpira, 1995). The main aim of these was to estimate the role of microorganisms in the biological cycling of organic material in the ecosystem.

\section{Protozoa}

In the 1980s studies of pelagic and benthic ciliates were started in the southern GoR in relation to their structural and functional role in the benthic biocoenoses and participation in the decomposition of allochthonous organic material in the pelagial. The productivity of several most abundant plankton ciliate species was estimated (Andrushaitis, 1990). As a result of the studies (incl. the ecotoxicological experiments) it was suggested that these organisms should be included in marine monitoring programmes (Boikova, 1984, 1989). 


\section{Mesozooplankton}

First data on mesozooplankton originate from the years of the Russian Baltic expedition of 1908-09 (Krabbi, 1913). Mostly qualitative data were collected in six stations by water layers during the terminal cruises in the 1920s and 1930s (Frisch \& Riikoja, 1929; Rapaport, 1929). Plankton hauls performed during different times of a day allowed Berzins (1932) to notice diel vertical migrations of two copepod species: Eurytemora hirundoides and Acartia bifilosa. Incidental finding of the alien copepod Acartia tonsa in a sample from the southern GoR led Berzins to re-examine older samples. He concluded that the alien copepod settled in the basin probably a few years before the regular zooplankton sampling started (Berzins, 1939).

After World War II systematic and comprehensive studies were started (Nikolaev, 1957; Nikolaev \& Krievs, 1957). These publications contain a description of the biological seasons of the Baltic Sea based on the studies of seasonal abundance dynamics and productivity fluctuations of mesozooplankton as well as changes in its species composition. Also, the relationship between the distribution of mesozooplankton and planktivorous fish was analysed (Nikolaev, 1961), stressing the importance of deep-water concentrations of zooplankton in planktivorous fish feeding. In the BaltNIIRH most of the studies were directed to zooplankton as a food resource mainly for the larval, young, and adult herring and the main factor determining the larval survival and formation of the year-class abundance (e.g., Rannak, 1958; Lisivnenko, 1961; Rannak \& Jakobson, 1962; Rannak \& Simm, 1979).

The impact of the bottom relief on the formation of the temporal and spatial maxima of copepod nauplii and the spawning of herring groups was shown by Ojaveer \& Simm (1975). Later the abundance and biomass dynamics of mesozooplankton by species, the community composition and the ecology (incl. in relation to main abiotic factors, pollution, and predators) of the main zooplankton species was treated. For example, the effect of marine eutrophication on the mesozooplankton community was shown by Simm (1982).

On the basis of a long-term dataset (1956-86) Sidrevics et al. (1993) studied the connections between the zooplankton abundance and productivity (by species) and the air temperature. Also, the impact of eutrophication and the related changes in the mesozooplankton community upon the condition of the herring stock and recruitment were discussed. The 40-years dataset of 1957-97 was a basis for studies of seasonal development of copepod abundance in relation to the temperature (warm vs. cold) and salinity (low and high) regime (Simm \& Ojaveer, 2000). Continuation of the long-term zooplankton surveys in the northern GoR throughout the 1990s enabled to reveal changes in the zooplankton structure after the invasion of the Ponto-Caspian predatory cladoceran Cercopagis pengoi (Ojaveer et al., 2000). 


\section{Ichthyoplankton}

Monitoring of larval fish abundance was carried out in stationary stations on herring (later on also smelt) spawning grounds in the northeastern GoR during 1946-98 in the May-July period. These studies were mainly aimed at predicting the potential level of the herring year-class abundance based on the number of larvae of different length groups (Rannak, 1958) to provide medium-term forecasts of herring catches. As larvae in the samples were determined to a species level (incl. both commercial and non-commercial species such as pikeperch, perch, smelt, gobies, sandeel, and others), the application range of the results was very wide: for instance, changes in the abundance of smelt and goby larvae have been attributed to increased pollution/eutrophication of their spawning grounds and nursery areas (Ojaveer \& Gaumiga, 1995).

Exstensive research on the distribution and abundance of the spring and autumn spawning herring larvae (and also juveniles), carried out on mothly basis from January to December in the eastern basin at depths from 5 to $35-40 \mathrm{~m}$ during the years 1956-63 was aimed at predicting herring year-class strength and commercial catches but also formed basis for taking protection measures of the herring stock. The larval surveys were accompanied by simultaneous studies on their food resources (mesozooplankton) and temperature regime. All samples and measurements were taken by water layers (Lisivnenko, 1970).

\section{Nektobenthos}

Mysids have been studied in the GoR since the 1950s. The first results, mainly on distribution but also on vertical migration and general biology, were published by Järvekülg (1960, 1961), Shurin (1961), Sanina (1961), and Chekhova (1961). However, these initial studies covered only a short period of the productive season and were fairly restricted in spatial scale. Long-term systematic investigations on the biology and ecology of mysids were started in the 1970s and continued until present. Among others, the following aspects were studied: reproduction of Neomysis vulgaris (Kotta, 1976), Mysis mixta, and M. relicta (Shvetsova, 1980); the life cycle and production of M. mixta (Shvetsova \& Shvetsov, 1990; Simm \& Kotta, 1992); spatio-temporal distribution pattern and vertical and horizontal migration of the most abundant mysids, the cold-water M. mixta, M. relicta, and the warm-water Neomysis integer, in relation to depth and temperature and salinity regimes (Kotta, 2003 and references therein); long-term abundance dynamics of mysids in relation to winter severity and summer air and water temperatures (Kotta, 1995).

\section{Macrozoobenthos}

According to F.S.B (1819, cited in Kotta et al., 1998) the first published record on molluscs originates from 1819. Although some activities were under- 
taken in both Estonia and Latvia also in the 1930s, systematic and detailed studies were started in the mid-1940s (Gaumiga \& Lagzdinsh, 1995). A significant contribution to macrozoobenthic investigations in the 1950s and 1960s was made by Shurin $(1953,1961)$, who studied the species composition and abundance and biomass distribution of macrozoobenthos in relation to depth and region, along with distinguishing and mapping six different communities according to the dominating taxa: Cerastoderma lamarcki, Mya arenaria, and Macoma baltica; Macoma baltica; Monoporeia affinis; Pontoporeia femorata; Dreissena polymorpha; and Mytilus edulis and Balanus improvisus.

The most important contribution to macrozoobenthos ecology of the GoR is the monograph by Järvekülg (1979) containing results of the basin-wide investigations during 1959-69 on the following general topics: abundance and biomass distribution by individual species, impact of various factors on zoobenthos distribution (incl. depth, salinity, sediment type, bottom macroflora, pollution, eutrophication, and competiton), classification of macrozoobenthic biocoenoses, distribution ecology of selected species and local populations of benthic glacial relicts in relation to their genesis. The same author (Järvekülg, 1979) described eight eco-zoogeographical groups: panboreal, boreal, lowerarctic-panboreal, lowerarctic-boreal, panarctic, panarctic-boreal, panarctic-panboreal, and the species of very large latitudinal distribution.

An important component of macrozoobenthos studies has been long-term dynamics (Gaumiga \& Lagzdinsh, 1995; Kotta \& Kotta, 1995). These sources reported a substantial abundance and biomass increase in macrozoobenthos at a scale of 30-40 years in the whole GoR and Pärnu Bay, respectively. The observed long-term changes were attributed to pollution and eutrophication. Impacts of these human-mediated effects are also evident in the spatial distribution of zoobenthos abundance and biomass and species composition in various parts of the basin (e.g., Kachalova, 1974; Lagzdinsh et al., 1987; Gaumiga \& Lagzdinsh, 1995). Most recently, substantial large-scale changes in the softbottom macrofaunal community were related to another type of human impacts the invasion of the North-American polychaete Marencelleria viridis (Cederwall et al., 1999).

\section{Fish and fisheries}

Proposals for regulating the fishery in Pärnu Bay were made already in 1887. The following measures were suggested: minimum mesh size for herring fishery, creation of artificial spawning sites, closure of fishery during the spawning time in the areas of artificial spawning sites, minimum size of fish allowed to be sold in market (by species), building of a fish ladder to the Pärnu River, and rearing of river trout after appropriate investigations (von Middendorff, 1887; see also Fig. 4). The final resolution of the First International Baltic Sea Fisheries Congress in 1910 stated that for the regulation of the herring fishery systematic applied fisheries investigations in the Baltic Sea within a frame of a special programme, 


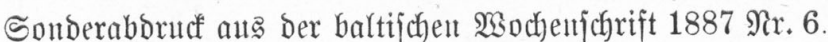

Sivländifhe Zlbtheilung der Rufitichen

Bejellichaft für fifhlucht und fifhfang.

\section{里 $\mathfrak{x} \mathfrak{x} \mathfrak{i}$ d $\mathfrak{r} \mathfrak{t}$}

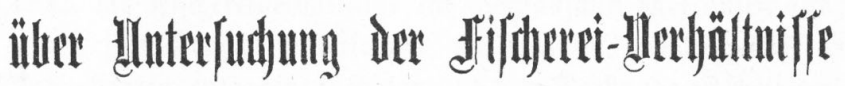

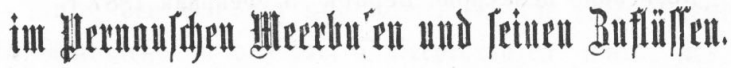

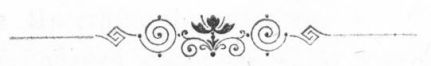

Sorvat.

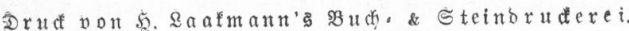

1887.

Fig. 4. Cover page of the reference of Middendorff (1887). 
especially in the GoR, was necessary. In the early 20th century the student P. Borissov made a comprehensive study of fishery issues in Riga and neighbouring areas, including fishing methods and fishing gear applied, the number of fishers and fishing gear, fish catches, and income of fishers, confiscation of fish, and manufacturing of fish products (Schneider, 1912; see also Fig. 5). He also investigated fisheries (incl. gear used by different fisheries, minimum legal fish size, fish exports, catches of selected fish, and their price) in the Pärnu Bay area (Borissov, 1914).

In the 1920s collection of standardized fishery statistics started both in Estonia and in Latvia. Studies of the most important commercial fishes (e.g., salmon Salmo salar, trout S. trutta, herring Clupea harengus membras, eel Anguilla anguilla, flounder Platichthys flesus) were developed. In the 1930s tagging experiments were an important item in the fisheries research. For example, A. Määr tagged eels in the Estonian part of the GoR (Pärnu Bay, Saaremaa Island) and in the Daugava estuary.

After World War II systematic fisheries investigations were started. The main components of these studies were investigations of age, length, and weight composition and the landings of commercially important fish species, estimation of their possible exploitation rates, and prognosis of catches (Rannak, 1954). Since the 1950s determination of the population structure of the main commercially important species, their fecundity, reproduction (incl. condition of reproduction areas), feeding, distribution, and migration by identification of causative factors was developed. The main goal of these studies was to provide a good basis for

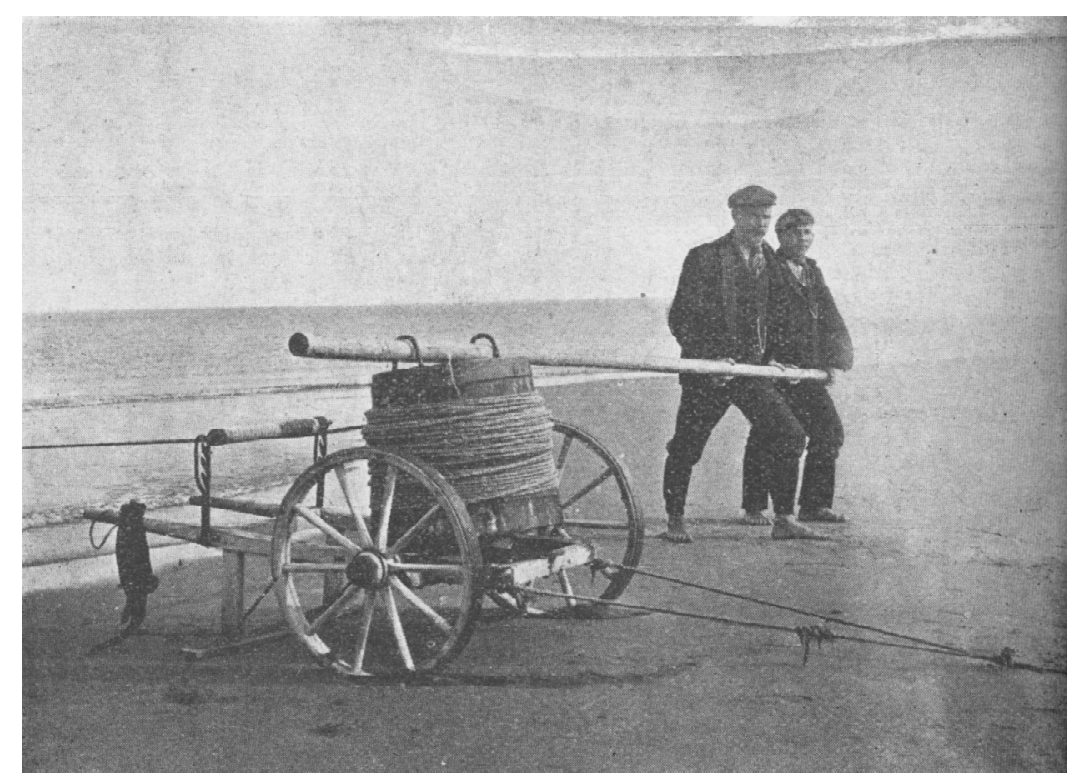

Fig. 5. Fishing with a seine in the early 20th century (from Schneider, 1914). 
catch prognosis. The most important commercial species - herring - received the most attention, with the systematic studies initiated by L. Rannak. She has determined the main stocks of spring herring in Estonian waters, their meristic characters, and body proportions. Clarification of the factors and processes responsible for the survival of herring embryos and larvae (Rannak, 1958) and the formation of recruitment (Rannak, 1971; Rannak \& Simm, 1979) enabled to forecast the year-class abundance before its entering into the exploited part of the stock. This was a mighty tool in granting the justification of Estonian prognoses of herring catches (Ojaveer \& Rannak, 1967). Based on the data from the mid1960s, an important basic contribution to the understanding of the feeding of young herring, incl. diet composition, feeding habits, seasonal dynamics of feeding activity, and condition of fish, was made by Trauberga (1970). In the 1960s, based on the data mainly from the GoR, several other basic studies were completed that created preconditions for the assessment of herring stocks by the virtual population analysis (VPA) method. The most important of them was the method of separation of herring stocks by means of their otolith structure (Ojaveer, 1962). This method, original for the Baltic Sea, has been exploited up to the present. Also, mortalities and yield per recruit curve of herring populations in the GoR were calculated some years earlier than for other populations in the Baltic (Ojaveer, 1974). These and other results of herring studies, completed up to the 1980s, are presented in a major monograph on the Baltic herring (Ojaveer, 1988).

Investigations on other commercial species have certainly been less extensive. However, the dynamics of the surrounding environment and the factors influencing the condition of stocks and fishery of several commercial species was systematically and regularly monitored. This formed the basis for scientific advice for exploitation. Such background information was collected and analysed for pikeperch Stizostedion lucioperca along with determining the factors responsible for the mortality and year-class strength of the fish (Erm, 1967, 1976; Lappalainen et al., 2000), for whitefish Coregonus lavaretus along with stock structure and abundance dynamics (Sõrmus, 1960, 1992), smelt Osmerus eperlanus (Gaumiga, 1967; Shestakov, 1967, 1970; Špilev, 1992), and vimba bream Vimba vimba (e.g., Erm, 1965). In addition, relatively rich material was also collected on flounder, salmon, perch Perca fluviatilis, and other commercial fishes (Kostrichkina, 1968; Evtyukhova, 1970; Shchukina, 1970; Mitans, 1975; Erm et al., 1980; Vitinsh, 1988).

Of less important commercial fishes, eelpout Zoarces viviparus has been studied from several aspects: general biology (Tanasijchuk, 1970), regularities of distribution and stock composition (Gaumiga, 1981), ecological groups (Ojaveer \& Lankov, 1997), and feeding characteristics including daily rhythm, diet composition in relation to fish age, length, depth zones, and seasons (Kostrichkina, 1968; Urtans, 1990, 1992). Of the non-commercial fishes the most abundant in the GoR is probably three-spined stickleback Gasterosteus aculeatus, which has been studied for several aspects of general biology and ecology (Vainu, 1964; Jakobson, 1970), feeding (Kostrichkina, 1970b; Ojaveer et al., 1997), reaction to various artificial 
lights (Tirzitis, 1980), and importantly, on the negative impact caused to the main commercial fishes of the basin via trophic interactions (Tanasijchuk et al., 1966). Amongst other fishes, some non-commercial species (e.g., fourhorned sculpin Triglopsis quadricornis and sea snail Liparis liparis) were also studied in a series of investigations on fish feeding relations (Kostrichkina, 1968, 1970a).

In order to obtain higher fish yields, more effective utilization of the available food resource by commercial fish should be achieved. The two ways proposed include: (1) reduction of the non-commercial planktivorous fishes (mainly sticklebacks and gobies) that are food competitors for herring and (2) introduction of valuable demersal fishes in order to utilize the rich benthic prey resource (Tanasijchuk et al., 1966).

The hydrological, hydrochemical, planktonological, ichthyological, etc. investigations, which were initially started as special studies in the 1940s-50s, were later amalgamated into complex ecosystem investigations with the aim to have the best data for practical output - prognoses and recommendations for fisheries management. Therefore, fisheries research institutions planned, carried out, and reported most marine studies since the 1960s as complex activities. In the 1980s fisheries management authorities required from scientists in addition to the chapters on assessments of fish stocks and recommendations for stock exploitations supplementary information on hydrology and hydrobiology (incl. on fish prey and predators).

\section{Marine mammals}

The following two seal species inhabit the GoR: the grey seal Halichoerus grypus and the ringed seal Phoca hispida. Seal hunting has traditionally been an important constituent of human activities of fisher villages especially on Kihnu, Ruhnu, and other islands and coasts of the northern gulf. Results of Estonian seal hunting were published in the journal Eesti Kalandus (Estonian Fishery) in the 1930s and the journal Abiks Kalurile (For the Fisherman) in the 1960s. The first results on the population abundance of ringed seals became available in the 1970s. However, the published abundance estimates from the 1970s and 1980s were later regarded as unreliable and exaggerated, mainly due to methodological reasons (Härkönen et al., 1998 and references therein). The first field survey with modern reliable techniques for both species of seals was accomplished in 1994 and repeated for the ringed seal in 1996 (Härkönen et al., 1998) but continued annually since then for the grey seal (Jüssi \& Jüssi, 2001). The recently published paper on a drastic drop in the abundance of both species of seals in the whole Baltic Sea during the 20th century, together with seal kill dynamics and community structure, includes also data from the GoR (Harding \& Härkönen, 1999). After the abundance of seals dropped to very low levels, investigations on fishery impacts to seal populations started: some data are available from the 1970s (Pilats, 1989) but more systematically from the 1990s (Anon., 2000). 


\section{Examples of complex interdisciplinary cruises}

Below we provide more detailed information on some selected complex surveys that were carried out during various decades of the 20th century. In these surveys measurements of different ecosystem parameters were taken simultaneously.

\section{The first Russian Baltic expedition}

The first Russian expedition on the Baltic Sea, headed by O. Grimm, was carried out on the navy transport boat Kompass in 1908. In the GoR, 11 main and 12 intermediate stations were sampled for several abiotic and biotic components of the ecosystem, such as water currents, temperature, salinity, oxygen concentration, species composition of phyto- and zooplankton, nekto- and macrozoobenthos, and fish. During this multidisciplinary cruise, first hydrological data for the open basin were obtained. Methods and equipment according to suggestions of ICES were employed (Laganovska \& Kachalova, 1990; Mardiste, 1995).

\section{Terminal cruises}

The thalassological observations carried out by K. Frisch and H. Riikoja were the first systematic studies in the basin. One cruise per year at 6 stations (Fig. 1) was made during the period of 1924-38, where hydrological, hydrochemical, and meteorological data were collected. Plankton was sampled during 1924-30. Methods approved by ICES were employed. The following parameters (by water layers) were measured: water temperature, transparency, density, salinity, oxygen concentration, oxygen saturation \%, alkalinity, $\mathrm{pH}$, transparency, and pressure of free carbonic acid (Fig. 2). Of meteorological indices, wind direction and strength, relative humidity, and cloudiness were measured.

Plankton samples, collected at 0-10 m, 10-25 m, 25-50 m, 50 m-bottom, were analysed both qualitatively (by species) and quantitatively (by abundance categories).

Of phytoplankton also cyanobacteria were studied. In zooplankton samples, including mollusca larvae, nektobenthic organisms, and appendiculariae were analysed. Results of the studies (original datasets) were published annually in Tartu Ülikooli Eesti Veekogude Uurimise Komisjoni Väljaanne (Publications of the Commission of the University of Tartu on Investigations of the Estonian Waterbodies) (e.g., Frisch \& Riikoja, 1929).

\section{Investigations of fish and the environment}

Monthly surveys were conducted by a small stern trawler at fixed depths/stations during the ice-free period in 1974-86 (at the Ruhnu-Pärnu transect) and 1994-96 (at the Ruhnu-Pärnu transect and the Irbe Strait, Fig. 1), to monitor differences in fish fauna and other biota in the hydrologically active mixing zones as compared with their neighbouring areas, as well as to follow the seasonal transformation and migration of mixing zones. For both periods, water temperature at surface and bottom and the abundance of all fish species (incl. non-commercial fishes), 
accompanied by biological analysis of the more abundant fish species were determined by experimental trawlings. In the latter period, the following studies were additionally undertaken: water temperature by water layers, Secchi depth, salinity, phytoplankton and chlorophyll $a$, abundance and biomass of mesozooplankton, fish stomach content, fish parasites. The material collected during these studies, together with other hydrological observations, has allowed scientists to explain both spatio-temporal changes in the abundance of the main components of the Baltic fish fauna (i.e., marine and freshwater species and glacial relicts) and long-term changes in the GoR ecosystem (Ojaveer, 1997; Ojaveer et al., 1999).

An important task of the cruises was to study the role of hydrological fronts in biological secondary production. Results of these studies formed a basis for the assessment of the state of the GoR ecosystem.

\section{SUMMARY}

1. Scientific data are available since the mid-18th century.

2. Until the 1940s (World War II), most studies were descriptive and of shorttime coverage. In the 20th century, some systematic investigations of monitoring type lasted over 10 years.

3. In the late 1940s systematic comprehensive studies commenced. They developed and widened and involved all the most important trophic levels including the interactions between the biotic and abiotic environment. Strong emphasis was on commercial fish stocks. Causative and predictive approach was applied.

4. Since the 1990s, partly due to the changed financing scheme, some longterm datasets have been broken. Emphasis is on short-term projects dealing with very specific questions/topics rather than long-term systematic investigation of the ecosystem.

\section{ACKNOWLEDGEMENTS}

The paper is a contribution to the Estonian Governmental Fundamental Research programme (0182579s03) and the History of Marine Animal Populations project of the Census of Marine Life programme (funded by the Alfred P. Sloan Foundation).

\section{REFERENCES}

Andrushaitis, A. 1990. The rate of multiplication of mass species of plankton ciliates in the Gulf of Riga. In The Ecology of Sea and Freshwater Ciliates. Protozoology, pp. 17-25. Nauka, Leningrad (in Russian).

Andrushaitis, A., Andrushaitis, G., Bitenieks, J., Lenshs, E. \& Priede, S. 1990. Balance of organic carbon of the Gulf of Riga. In Proceedings of the 17th Conference of the Baltic Oceanographers, Norrköping 1990, pp. 59-66. SMHI, Norrköping. 
Andrushaitis, G. P. (ed.) 1987. Hydrochemical and Hydrobiological Characteristics and Zonation of the Littoral Zone of the Baltic Sea, Gulf of Riga and Gulf of Finland. Zinatne, Riga (in Russian).

Andrushaitis, G. P. \& Boikova, E. E. 1982. Impact of zinc and copper on brackishwater protists. Eksp. Vodn. Toksikol., 8, 7-18 (in Russian).

Anon. 1807. Register of meteorological observations carried out in the port of Reval in 1806 by astronomer of the class eight Ivanov, selected from monthly meteorological journals presented to the department. Zapiski, isdavaemye Gosudarstvennym Admiralteitskim Departmentom, otnosyasshchiesya k Moreplavaniyu, Naukam i Slovesnosti, 1, 350-356 (in Russian).

Anon. 1871. Pilot Book on Russian Coast of the Baltic Sea. Izd. Gidrograficheskogo departamenta, Sankt-Peterburg (in Russian).

Anon. 2000. Riiklik mereseire programm. Bioloogilise mitmekesisuse seire. Seireprojekt 'hülged'. Annual Report. Estonian Marine Institute, Tallinn.

Apine, S. \& Botva, U. 1982. Microbiological indices of the sanitary condition of the seashore margin of the Gulf of Riga. In Biology of the Baltic Sea. Environment and Hydrobiology of the Gulf of Riga, pp. 123-130. Zinatne, Riga (in Russian).

Arsenyeva, N. Y. 1972. Data on hyrological regime of the seas and estuaries of USSR. In Main Hydrological Characteristics. Baltic Sea. Central Part of the Baltic Sea and the Gulf of Riga. Sea Level, Currents, Water Temperature, Ice, Water Salinity. Rizhskaya gidrometeorologicheskaya observatorya, Riga (in Russian).

Auninsh, E. A. 1961. Seasonal variations of hydrochemical conditions in the Gulf of Riga (on data of 1959). Tr. GOIN, 59, 98-112 (in Russian).

Auninsh, E. A. 1965. Nutrients in the water of the Gulf of Riga. Tr. GOIN, 83,172-206 (in Russian).

Auninsh, E. A. 1966. Ion composition and water salinity of the Gulf of Riga. Sb. Rabot RGMO, 10, 55-79 (in Russian).

Balode, M. 1982. Impact of lead on structural and functional characteristics of natural phytoplankton communities of the Gulf of Riga. Eksp. Vodn. Toksikol., 8, 33-50 (in Russian).

Balode, M. \& Tomsone, S. 1984. Development of phytoplankton in the southern part of the Gulf of Riga according to the state of mineral nutrition. In Biology of the Baltic Sea. Hydrobiology of the Gulf of Riga, pp. 81-95. Zvaigzne, Riga (in Russian).

Baranov, A. N. 1970. Currents in the Gulf of Riga and the Strait of Irbe. Sb. Rabot RGMO, 13, 87 (in Russian).

Berg, P. G. (ed.) 1985. Annual Hydrochemical Data on Sea-water Quality of Latvian SSR, 1984. LatvUGKS, Riga (in Russian).

Berzins, B. 1932. Das Plankton der lettischen Terminfahrt im Frühjahr 1928. (Rigascher Meerbusen und Baltisches Meer). Fol. Zool. Hydrobiol., 4, 69-102.

Berzins, B. 1939. Acartia tonsa Dana in the Gulf of Riga. Fol. Zool. Hydrobiol., 10, 484-486.

Berzins, B. 1942. Hydrographische Untersuchungen der Hydrobiologischen Station im Rigaer Meerbusen und im Baltischen Meere. X.-XI. Fol. Zool. Hydrobiol., 11, 361-369.

Berzinsh, V. 1979. Some pecularities of water temperature distribution in the Gulf of Riga during the summer. In Biological Productivity, Resources of the Baltic Sea and Their Rational Utilization, pp. 4-65. Zinatne, Riga (in Russian).

Berzinsh, V. 1980. Interannual and seasonal variation of water salinity of the Gulf of Riga. Rybokhozyajstvennye issledovanya v bassejne Baltijskogo morya, 15, 3-12 (in Russian).

Berzinsh, V. 1995. Dynamics of hydrological parameters of the Gulf of Riga. In Ecosystem of the Gulf of Riga between 1920 and 1990 (Ojaveer, E., ed.), pp. 8-31. Estonian Academy Publishers, Tallinn.

Berzinsh, V., Bethers, U. \& Sennikovs, J. 2001. Hydrographic regime of the Gulf of Riga between the years 1991 and 1995. Proc. Latvian Acad. Sci., Section B, 4, 152-159.

Boikova, E. E. 1984. Benthos infusoria in the coastal area of the Gulf of Riga. In Biology of the Baltic Sea. Hydrobiology of the Gulf of Riga, pp. 120-127. Zvaigzne, Riga (in Russian). 
Boikova, E. E. 1989. Protozoans - Biomonitors of Marine Environment. Zinatne, Riga (in Russian). Borissov, P. 1914. Die Fisherei im Pernauschen Meerbusen und im Pernaufluss. Jahrbuch der Abteilungen der kaiserlich Russischen Gesellscaft für Fischzucht und Fischfang in Est-, Livund Kurland, VII, 69-72.

Cederwall, H., Jermakovs, V. \& Lagzdinsh, G. 1999. Long-term changes in the soft-bottom macrofauna of the Gulf of Riga. ICES J. Mar. Sci., 56 (Suppl.), 41-48.

Chekhova, V. A. 1961. Vertical migration of Mysis mixta and Mysis oculata v. relicta in the Gulf of Riga. Tr. NIIRKH SNH LatvSSR, 3, 307-327 (in Russian).

Erm, V. 1965. Riia lahe vimma rännetest, looduslikest varudest ja abinõudest vimmavarude kaitseks. Abiks Kalurile, 2, 14-18.

Erm, V. 1967. On changes of pikeperch catch in Pärnu Bay and biological basis for regulation of fishery. Rybokhozyajstvennye issledovaniya v bassejne Baltijskogo morya, 3, 109-118 (in Russian).

Erm, V. 1976. On the factors determining pike-perch year-class strength in Pärnu Bay of Pärnu. Rybokhozyajstvennye issledovaniya v bassejne Baltijskogo morya, 12, 51-58 (in Russian).

Erm, V., Rannak, L. \& Veldre, I. 1980. Riia laht ja selle tähtsamaid töönduskalu. Eesti Loodus, XXIII, 9, 573-579.

Evtyukhova, B. K. 1970. Some regularities of growth rate dynamics and fecundity of the Baltic salmon. Tr. BaltNIIRH, IV, 284-334 (in Russian).

Fischer, J. B. 1778. Versuch einer Naturgeschichte von Livland. Leipzig.

Fridman, A. M. (ed.) 1969. Marine Hydrochemical Bulletin 1969. Nos. 1-3. UGMS Latv. SSR, Riga (in Russian).

Frisch, K. 1924. Sea-ice observations in Estonia during winter 1923/24. Tartu Ülikooli Eesti Veekogude Uurimise Komisjoni Väljaanne, 1.

Frisch, K. \& Riikoja, H. 1925. Die Estnischen Terminfahrten in den Jahren 1923 und 1924. Tartu Ülikooli Eesti Veekogude Uurimise Komisjoni Väljaanne, 2.

Frisch, K. \& Riikoja, H. 1928. Die Estnischen Terminfahrten in den Jahren 1925 und 1926. Tartu Ülikooli Eesti Veekogude Uurimise Komisjoni Väljaanne, 5.

Frisch, K. \& Riikoja, H. 1929. Die Estnischen Terminfahrten in den Jahren 1927 und 1928. Tartu Ülikooli Eesti Veekogude Uurimise Komisjoni Väljaanne, 9.

Frisch, K. \& Riikoja, H. 1931. Die Estnischen Terminfahrten in den Jahren 1929 und 1930. Tartu Ülikooli Eesti Veekogude Uurimise Komisjoni Väljaanne, 16.

F.S.B. 1819. Existence simultanee de mollusques marins et fluviatiles dans le Golf de Livonia. Bull. Soc. Philom. Paris, 72.

Gaumiga, R. 1967. On the role of Daugava River in recruitment of stocks of spring-spawning fish. Rybokhozyajstvennye issledovaniya v bassejne Baltijskogo morya, 3, 197-204 (in Russian).

Gaumiga, R. 1981. Regularities of distribution and stock composition of eelpout in the Gulf of Riga. Rybokhozyajstvennye issledovaniya $v$ bassejne Baltijskogo morya, 16, 39-45 (in Russian).

Gaumiga, R. \& Lagzdinsh, G. 1995. Macrozoobenthos. In Ecosystem of the Gulf of Riga between 1920 and 1990 (Ojaveer, E., ed.), pp. 198-211. Estonian Academy Publishers, Tallinn.

Goebel, C. C. Fr. 1845. Das Seebad bei Pernau an der Ostsee in physikalisch-chemisher und topographisch-statistischer Beziehnung, nebst einer vergleichenden chemischen Untersuchung des Ostseewassers bei Reval, Hapsal und Pernau, und allgemeinen Bemerkungen über die Seebäder. Dorpat und Leipzig.

Harding, K. C. \& Härkönen, T. J. 1999. Development in the Baltic Grey Seal (Halichoerus grypus) and Ringed Seal (Phoca hispida) populations during the 20th century. Ambio, 28, 619-627.

Härkönen, T., Stenman, O., Jüssi, M., Jüssi, I., Sagitov, R. \& Verevkin, V. 1998. Population size and distribution of the Baltic ringed seal (Phoca hispida botnica). In Ringed Seals in North Atlantic (Heide-Jorgensen, M. P. \& Lydersen, C., eds.), pp. 167-180. NAMMCO Scientific Publications, Troms $\varnothing$.

Jakobson, T. 1970. Biology of three-spined stickleback Gasterosteus aculeatus in Pärnu Bay. Tr. BaltNIIRH, 4, 171-192 (in Russian). 
Jansone, B. 1995. Concentration of chlorophyll "a" in the Gulf of Riga. In Ecosystem of the Gulf of Riga between 1920 and 1990 (Ojaveer, E., ed.), pp. 127-130. Estonian Academy Publishers, Tallinn.

Jansone, B. 1996. Chorophyll a. In Third Periodic Assessment of the State of the Marine Environment of the Baltic Sea, 1989-1993. Background document. Baltic Sea Environ. Proc., No. 64. B. 68. Helsinki.

Järvekülg, A. 1960. Materjale Pärnu lahe põhjaloomastiku kohta. Eesti NSV TA Toim. Biol., 9, 199_ 214.

Järvekülg, A. 1961. Mõnede bentiliste ja nektobentiliste selgrootute levikust Riia lahe kirdeosas. Eesti NSV TA Toim. Biol., 10, 214-230.

Järvekülg, A. 1979. Benthic Fauna in the Eastern Part of the Baltic Sea. Valgus, Tallinn (in Russian).

Jevrejeva, S. 2001. Severity of winter seasons in the northern Baltic Sea between 1529 and 1990: reconstruction and analysis. Clim. Res., 17, 55-62.

Jüssi, I. \& Jüssi, M. 2001. Action plan for Grey Seals in Estonia 2001-2005. Eesti Ulukid, 7.

Kachalova, O. L. 1974. Changes in benthic fauna in Daugava River estuary as a result of pollution. In Self-purification Factors of the Daugava River Estuary, pp. 90-105. Zinatne, Riga (in Russian).

Kalnozols, P. A. 1973. The distribution and ecology of benthic algae in the Gulf of Riga. In Annual Report VNIRO, pp. 100-109 (in Russian).

Kalveka, B. 1983. The peculiarities of phytoplankton development in the Gulf of Riga in 1978-1980. Rybokhozyajstvennye issledovaniya v bassejne Baltijskogo morya, 18, 3-9 (in Russian).

Kalveka, B. 1996. Phytoplankton. Third Periodic Assessment of the State of the Marine Environment of the Baltic Sea, 1989-1993. Background document. Baltic Sea Environ. Proc., No. 64. B, 66-68. Helsinki.

Kautsky, H., Martin, G., Mäkinen, A., Borgiel, M., Vahteri, P. \& Rissanen, J. 1999. Structure of phytobenthic and associated animal communities in the Gulf of Riga. Hydrobiologia, 393, 191-200.

Kirde, K. 1940. Termiinsõidud Eesti välisvetes 1935-1939. Loodusvarade Instituudi Avaldised, 3.

Kochish, F. I., Matisone, M. P. \& Melberga, A. G. 1967. Sanitary characteristics of the coastal zone of the Gulf of Riga. In Gulfs as Recipients of Wastewaters, pp. 86-98. Zinatne, Riga (in Russian).

Kostrichkina, E. M. 1968. Feeding relations of fishes in the Gulf of Riga. Rybokhozyajstvennye issledovaniya v bassejne Baltijskogo morya, 4, 109-135 (in Russian).

Kostrichkina, E. M. 1970a. Feeding electivity of fishes of the Gulf of Riga. Rybokhozyajstvennye issledovaniya v bassejne Baltijskogo morya, 5, 97-109 (in Russian).

Kostrichkina, E. M. 1970b. Feeding of three-spined stickleback in the Gulf of Riga. Tr. BaltNIIRH, IV, 339-348.

Kotta, I. A. 1976. About breeding and the changes in the abundance and biomass of Neomysis vulgaris Thompson in Pärnu Bay. Rybokhozyajstvennye issledovaniya v bassejne Baltijskogo morya, 12, 44-50 (in Russian).

Kotta, I. 1995. Nektobenthos (Mysidacea). In Ecosystem of the Gulf of Riga between 1920 and 1990 (Ojaveer, E., ed.), pp. 187-197. Estonian Academy Publishers, Tallinn.

Kotta, I. 2003. Population ecology of mysids in the Gulf of Riga. Tallinn Pedagogical Univ., Diss. Natural Sci., 7.

Kotta, J. \& Kotta, I. 1995. The state of macrozoobenthos of Pärnu Bay in 1991 as compared to 1959-1960. Proc. Estonian Acad. Sci. Ecol., 5, 26-37.

Kotta, J., Kotta, I., Martin, G. \& Kukk, H. 1998. A survey of data published on the littoral zoobenthos of the Gulf of Riga. Proc. Estonian Acad. Sci. Biol. Ecol., 47, 83-97.

Kotta, J., Paalme, T., Martin, G. \& Mäkinen, A. 2000. Major changes in macroalgae community composition affect the food and habitat preference of Idothea baltica. Internat. Rev. Hydrobiol., 5-6, 697-705.

Krabbi, A. I. 1913. Report on plankton collected by the Baltic expedition during July-August and September in 1909. Tr. Russkoj Baltijsk. Eksped., 2, 103-132 (in Russian). 
Kukk, H. 1995. Phytobenthos. In Ecosystem of the Gulf of Riga between 1920 and 1990 (Ojaveer, E., ed.), pp. 131-138. Estonian Academy Publishers, Tallinn.

Kulikova, I. 1995. Mercury content in the ecosystem of the Gulf of Riga. In Ecosystem of the Gulf of Riga between 1920 and 1990 (Ojaveer, E., ed.), pp. 80-103. Estonian Academy Publishers, Tallinn.

Kumsare, A., Jurane, A. \& Kachalova, O. L. 1974. Algal flora and protozoa in the littoral zone of the southern part of the Gulf of Riga. Biol. Baltijsk. Morya, 1, 130-143 (in Russian).

Laganovska, R. Yu. \& Kachalova, O. L. 1990. Hydrobiological Investigations in the Baltic Sea. Zinatne, Riga (in Russian).

Lagzdinsh, G. S., Saule, A. H. \& Pallo, P. E. 1987. Changes in benthic macrofauna as an indicator of eutrophication in the southern part of the Gulf of Riga. In Biological Resources of Water Bodies in the Baltic Sea Basin, pp. 101-102. Vilnius (in Russian).

Lappalainen, J., Erm, V., Kjellman, J. \& Lehtonen, H. 2000. Size-dependent winter mortality of age-0 pikeperch (Stizostedion lucioperca) in Pärnu Bay, the Baltic Sea. Can. J. Fish. Aquat. Sci., 57, 451-458.

Laznik, M. M., Vidnere, E. E. \& Lyulko, I. L. 1988. Contemporary ionic composition of the Gulf of Riga. In Regime Forming Factors, Hydrological and Hydrochemical Processes in Seas of the USSR, pp. 187-196. Gidrometeoizdat, Leningrad (in Russian).

Lisivnenko, L. N. 1961. Plankton and feeding of herring larvae in the Gulf of Riga. Tr. NIIRH, SNH Latv SSR, 3, 105-138 (in Russian).

Lisivnenko, L. N. 1970. Importance of the coastal zone of the Gulf of Riga for herring recruitment. Tr. BaltNIIRH, IV, 145-160 (in Russian).

Marcinkevicha, S. 1974. Distribution of oil-oxidizing bacteria in the southern part of the Gulf of Riga. In Biology of the Baltic Sea. Hydrochemistry and Hydrobiology of the Gulf of Riga, pp. 110-118. Zinatne, Riga (in Russian).

Marcinkevicha, S. 1984. Quantitative estimation of physiological groups of aquatic microorganisms in the southern part of the Gulf of Riga. In Biology of the Baltic Sea. Hydrobiology of the Gulf of Riga, pp. 28-39. Zinatne, Riga (in Russian).

Marcinkevicha, S. \& Zute, S. 1974. Quantitative distribution of microbes in the littoral water mass of the Gulf of Riga. In Biology of the Baltic Sea. Hydrochemistry and Hydrobiology of the Gulf of Riga, pp. 96-109. Zinatne, Riga (in Russian).

Mardiste, H. H. 1964. Currents of the Muhu-Vain straits. Sb. rabot Tallinsk. GMO, 2, 70-80 (in Russian).

Mardiste, H. 1995. Eestit piirava mere hüdroloogilise uurimise ajalugu (kuni 1917. aastani). In Teaduse ajaloo lehekülgi Eestist. XI kogumik, pp. 58-78. Estonian Academy Publishers, Tallinn.

Martin, G. 2000. Phytobenthic communities of the Gulf of Riga and the inner sea of the WestEstonian Archipelago. Diss. Biol. Univ. Tartu, 64.

Matisone, M. 1974a. Seasonal distribution of temperature and water oxidization in the southern part of the Gulf of Riga. In Biology of the Baltic Sea. Hydrochemistry and Hydrobiology of the Gulf of Riga, pp. 9-27. Zinatne, Riga (in Russian).

Matisone, M. 1974b. Seasonal changes in salinity in the southern part of the Gulf of Riga under the influence of freshwater inflow. In Biology of the Baltic Sea. Hydrochemistry and Hydrobiology of the Gulf of Riga, pp. 39-61. Zinatne, Riga (in Russian).

Matisone, M. \& Trautmanis, I. 1982. Hydrochemical investigations in the southern part of the Gulf of Riga. In Biology of the Baltic Sea. Environment and Hydrobiocoenoses, pp. 21-47. Zinatne, Riga (in Russian).

Mayer, R. 1926. Hidrografiski juras patašanas darbi Latvija. LU Raksti (Riga), 15, 513-534.

Middendorff, F., von 1887. Bericht über Untersuchung der Fischerei-verhältnisse im Pernauschen Meerbusen und seinen Zuflüssen. Livländische Abtheilungen der Russischen Gesellschaft für Fischzucht und Fischfang. Sonderabdruck aus der baltischen Wochenschrift, 6, 3-7. 
Mitans, A. R. 1975. Efficiency of natural and artificial reproduction of Baltic salmon as the result of peculiarities in its freshwater period. Rybokhozyajstvennye issledovaniya $v$ bassejne Baltijskogo morya, 11, 110-152 (in Russian).

Nikolaev, I. I. 1950. The main ecological-geographical complexes of phytoplankton of the Baltic Sea and their distribution. Bot. Zh., 35, 602-611 (in Russian).

Nikolaev, I. I. 1957. Biological seasons of the Baltic Sea. Tr. Latv. Otd. VNIRO, II, 115-140 (in Russian).

Nikolaev, I. I. 1961. Plankton as a factor for distribution and productivity of planktivorous fish in the Baltic Sea. Tr. Soveshch. Dinam. Chislennosti Ryb, 13, 364-373 (in Russian).

Nikolaev, I. I. \& Krievs, H. K. 1957. Productivity and conditions for development of plankton in the central Baltic Sea and the Gulf of Riga in 1955-1956. Tr. Latv. Otd. VNIRO, II, 39-82 (in Russian).

Ojaveer, E. 1962. Herring otolith investigations in the North-eastern Baltic. ICES C.M. 1962. Herring Committee, No. 134.

Ojaveer, E. 1974. On mortality rates of herring seasonal races in the northeastern Baltic. Rapp. P-v. Reun. Cons. int. Explor. Mer., 166, 140-144.

Ojaveer, E. A. 1988. The Baltic Herring. Agropromizdat, Moscow (in Russian).

Ojaveer, E. (ed.) 1995. Ecosystem of the Gulf of Riga between 1920 and 1990. Estonian Academy Publishers, Tallinn.

Ojaveer, E. \& Gaumiga, R. 1995. Cyclostomes, fishes and fisheries. In Ecosystem of the Gulf of Riga between 1920 and 1990 (Ojaveer, E., ed.), pp. 212-267. Estonian Academy Publishers, Tallinn.

Ojaveer, E. A. \& Rannak, L. A. 1967. Methods of composition of forecasts for herring commercial catches in the North-eastern Baltic. Tr. VNIRO, 12, 149-157.

Ojaveer, E., Rannak, L. \& Laevastu, T. 2001. One and a Half Centuries of Sea and Fisheries Investigations in Estonia. Estonian Academy Publishers, Tallinn.

Ojaveer, E. \& Simm, M. 1975. Effect of zooplankton abundance on time and place of reproduction of Baltic herring groups. Merentutkimuslait. Julk., 239, 139-145.

Ojaveer, H. 1997. Composition and dynamics of fish stocks in the Gulf of Riga ecosystem. Diss. Biol. Univ. Tartu., 31.

Ojaveer, H. \& Lankov, A. 1997. Adaptation of eelpout, Zoarces viviparus (L.) to spatially changing environment on the coastal slope of the Gulf of Riga (Baltic Sea). ICES C.M. 1997/EE:03.

Ojaveer, H., Lankov, A., Lumberg, A. \& Turovski, A. 1997. Forage fishes in the brackish Gulf of Riga ecosystem. In Forage Fishes in Marine Ecosystems. Proceedings of the International Symposium on the Role of Forage Fishes in Marine Ecosystems. Alaska Sea Grant College Program Report No. 97-01. University of Alaska, Fairbanks, Anchorage, 293-309.

Ojaveer, H., Lankov, A., Eero, M., Kotta, J., Kotta, I. \& Lumberg, A. 1999. Changes in the ecosystem of the Gulf of Riga from the 1970s to the 1990s. ICES J. Mar. Sci., 56 (Suppl.), 33-40.

Ojaveer, H., Simm, M., Lankov, A. \& Lumberg, A. 2000. Consequences of invasion of a predatory cladoceran. ICES C.M. 2000/U:16.

Olesen, M., Lundsgaard, C., \& Andrushaitis, A. 1999. Influence of nutrients and mixing of the primary production and community respiration in the Gulf of Riga. J. Mar. Syst., 23, 127-143.

Orav, H., Kotta, J. \& Martin, G. 2000. Factors affecting the distribution of benthic invertebrates in the phytal zone of the north-eastern Baltic Sea. Proc. Estonian. Acad. Sci. Biol. Ecol., 49, 253-269.

Paalme, T., Kukk, H., Kotta, J. \& Orav, H. 2002. 'In vitro' and 'in situ' decomposition of nuisance macroalgae Cladophora glomerata and Pilayella littoralis. Hydrobiologia, 475/476, 469476.

Pastors, A. A. 1954. Water exchange between the Baltic Sea and the Gulf of Riga. Tr. GOIN, 19, 104-156 (in Russian). 
Pastors, A. A. 1967. Water and heat balance of the Gulf of Riga. In Gulfs as Recipients of Wastewaters, pp. 8-33. Zinatne, Riga (in Russian).

Pastors, A. A. 1969. Water and Air Temperature in the Aquatory of the Gulf of Riga. Riga (in Russian).

Pilats, V. 1989. Seal distribution and fishery-seal interactions in the eastern Baltic. NNA-Berichte, 2/2, 107-114.

Platpira, V. 1985. Microbes and Transformation of Petroleum Hydrocarbons in the Marine Environment. Zinatne, Riga (in Russian).

Platpira, V. 1995. Heterotrophic bacteria. In Ecosystem of the Gulf of Riga between 1920 and 1990 (Ojaveer, E., ed.), pp. 139-159. Estonian Academy Publishers, Tallinn.

Pullisaar, T. 1961. Märkmeid Pärnu lahe põhjataimestiku kohta. ENSV TA Toim. Biol., 10, 340346.

Putnins, R. 1930. Les croisièries thalassologiques latviennes au printemps de 1929. Fol. Zool. Hydrobiol., 1, 149-159.

Rannak, L. A. 1954. Spawning areas, spawning and estimation of the strength of herring yearclasses in the waters of the Estonian SSR. Tr. VNIRO, 26, 24-48 (in Russian).

Rannak, L. A. 1958. Abundance estimations of herring embryos and larvae in the northern part of the Gulf of Riga and the main factors determining their survival. Tr. VNIRO, 34, 7-18 (in Russian).

Rannak, L. 1971. On the factors determining the abundance of recruitment in the spring spawning herring of the eastern Baltic. ICES CM 1971 Special Meeting on 'Cod and herring in the Baltic', Herring, 11.

Rannak, L. \& Jakobson, T. O. 1962. On feeding of herring in relation with its development. Gidrobiol. Issl., 2, 239-249 (in Russian).

Rannak, L. \& Simm, M. 1979. Dependence of abundance of the Gulf of Riga spring herring yearclasses on the supply of larval food. ICES C.M. 1979/J:9.

Rapaport, M. 1929. Das Oberflächenplankton der Küstengewässer Lettlands im Jahre 1925. Fol. Zool. Hydrobiol., 1, 63-104.

Rudzroga, A. 1974a. Phytoplankton species in the Gulf of Riga. In Biology of the Baltic Sea. Hydrochemistry and Hydrobiology of the Gulf of Riga, pp. 144-164. Zinatne, Riga (in Russian).

Rudzroga, A. 1974b. Distribution of plankton algae in the littoral part of the Gulf of Riga. In Biology of the Baltic Sea. Hydrochemistry and Hydrobiology of the Gulf of Riga, pp. 165-176. Zinatne, Riga (in Russian).

Sanina, L. V. 1961. About the biology of Neomysis vulgaris Thompson in the Gulf of Riga. Tr. NIIRKH SNKH Latv. SSR, 3, 293-306 (in Russian).

Sass, A. F. v. 1865. Untersuchungen über die Niveauverschiedenheit des Wasserspiegels der Ostsee. Bull. Acad. Imper. Sci. St. Petersbourg, 8, 65-81.

Schneider, G. 1912. Paul Borissow: Das Fishereigewerbe in Riga und Umgegend. Jahrbuch der Abteilungen der kaiserlich Russischen Gesellscaft für Fischzucht und Fischfang in Est-, Livund Kurland, V, 26-75.

Schneider, G. 1914. Abbildungen zu P. G. Borissow 'Das fischereigewerbe in Riga und Umgegend'. Jahrbuch der Abteilungen der kaiserlich Russischen Gesellscaft für Fischzucht und Fischfang in Est-, Liv- und Kurland, VII, 60-66.

Schweder, G. 1882. Salzgehalte des Rigascher Meerbusens. Korrespondenzblatt des NaturforscherVereins zu Riga, 25, 41-43.

Seisuma, Z. \& Legzdina, M. 1995. Heavy metals in water, sediments and organisms of the Gulf of Riga. In Ecosystem of the Gulf of Riga between 1920 and 1990 (Ojaveer, E., ed.), pp. 51-79. Estonian Academy Publishers, Tallinn.

Seisuma, Z. K., Kulikova, I. R., Marcinkevicha, S. Ya., Rudzroga, A. I., Boikova, E. Ye., Legzdina, M. B., Andrushaitis, A. G. \& Dzerve, A. E. 1986. Impact of Heavy Metals on the Plankton Ecosystem of the Gulf of Riga. Zinatne, Riga (in Russian). 
Seisuma, Z., Pedersen, B. \& Larsen, B. 1998. Vertical distribution of heavy metals and total C and $\mathrm{N}$ in sediments of the Gulf of Riga. Proc. Latvian Acad. Sci., Section B, 52, suppl., 77-80.

Shchukina, I. N. 1970. Feeding of some demersal fish in Pärnu Bay. Rybokhozyajstvennye issledovaniya v bassejne Baltijskogo morya, 5, 110-121 (in Russian).

Shestakov, V. G. 1967. On reproduction biology of smelt in Pärnu Bay. Rybokhozyajstvennye issledovaniya v bassejne Baltijskogo morya, 3, 119-128 (in Russian).

Shestakov, V. G. 1970. Feeding of smelt in Pärnu Bay. Rybokhozyajstvennye issledovaniya v bassejne Baltijskogo morya, 4, 349-360 (in Russian).

Shurin, A. T. 1953. Benthic fauna of the Gulf of Riga. Tr. Latv. Otd. VNIRO, 1, 77-113 (in Russian).

Shurin, A. T. 1961. Groups of benthic fauna of the Gulf of Riga. Tr. NIIRH, SNH Latv. SSR, III, 343-368 (in Russian).

Shvetsova, G. M. 1980. On reproduction of two species of relict and arctic mysids in the Gulf of Riga. Rybokhozyajstvennye issledovaniya v bassejne Baltijskogo morya, 15, 108-117 (in Russian).

Shvetsova, G. M. \& Shvetsov, F. G. 1990. Production of M. mixta in the northeastern and eastern parts of the Baltic Sea. Gidrobiol. Zh., 26, 24-29 (in Russian).

Sidrevics, L., Line, R., Berzinsh, V. \& Kornilovs, G. 1993. Long-term changes of zooplankton abundance in the Gulf of Riga. ICES C.M. 1993/L:15.

Simm, M. 1982. Zooplankton dynamics in Pärnu Bay suffering anthropogenic eutrophication. In Problems of Contemporary Ecology, p. 110. Tartu (in Russian).

Simm, M. \& Kotta, I. 1992. The life cycle and production of Mysis mixta in the Gulf of Riga. In Taxonomy, Biology and Ecology of (Baltic) Mysids (Mysidacea, Crustacea) (Köhn, J., Jones, M. \& Moffat, A., eds.), pp. 45-54. Rostock University.

Simm, M. \& Ojaveer, E. 2000. Dynamics of copepods and fish larvae in Pärnu Bay (NE part of the Gulf of Riga) in the spring-summer period. Proc. Estonian Acad. Sci. Biol. Ecol., 49, 317326.

Skuja, H. 1924. Beitrag zur Algenflora des Rigaschen Meerbusens. Acta Univ. Latviensis, 10, 373-392.

Sõrmus, I. 1960. Merisiiast Riia lahes ja Hiiumaa vetes. Abiks Kalurile, 20, 4-5.

Sõrmus, I. 1992. Eesti rannikuvete siiavarude seisundist. Eesti Kalandus, 5-6, 1-3.

Špilev, H. 1992. Meritindi varudest 1991. aastal. Abiks Kalurile, 4, 7.

Stakle, P. 1931. Observations fydrométriques en Lettonie jusqu' au 31.X 1929. Ministère des Finances, Departament de la Marine, Riga (in French and Latvian).

Strand, E. 1940. Hydrographische Untersuchungen der Hydrobiologischen Station im Rigaer Meerbusen und im Baltischen Meere. IX. Fol. Zool. Hydrobiol., 10, 508-526.

Strand, E. \& Ozolinsh, V. 1929-1936. Hydrographische Untersuchungen der Hydrobiologischen Station im Rigaer Meerbusen und im Baltischen Meere. Fol. Zool. Hydrobiol., 1, 53-62, 149-159; 3, 250-256; 4, 58-62, 271-276; 5, 38-40, 315-323; 7, 30-37; 8, 288-290; 9, $84-89$.

Suschenya, L. 1961. On plankton primary productivity in the Gulf of Riga. Tr. NIIRH, 26, 118-136 (in Russian).

Suursaar, Ü. \& Astok, V. 1996. Studies on measuring and modelling the water and nutrient exchange of the Gulf of Riga. EMI Rep. Ser., 3. Eesti Mereinstituut. Tallinn.

Suursaar, Ü. \& Tenson, J. 1998. Hydrochemical regime and productivity of the Pärnu Bay in 1968-1996. In More Studies on the Water Exchange and the Nutrients of the Gulf of Riga (Suursaar, Ü. \& Astok, V., eds.). EMI Rep. Ser., 9, 91-117. Eesti Mereinstituut, Tallinn.

Tamminen, T. \& Seppälä, J. 1999. Nutrient pools, transformations, ratios, and limitation in the Gulf of Riga, the Baltic Sea, during four successional stages. J. Mar. Syst., 627, 83-106.

Tanasijchuk, V. S. 1970. Biology of eelpout (Zoarces viviparus L.) in the Gulf of Riga. Tr. BaltNIIRH, 4, 161-171 (in Russian). 
Tanasijchuk, V. S., Shurin, A. T., Gaumiga, R. Y., Kairov, E. A., Kostrichkina, E. M. \& Trauberga, E. F. 1966. Ways of increasing fish production of the Gulf of Riga. Rybokhozyajstvennye issledovaniya $v$ bassejne Baltijskogo morya, 1, 49-60 (in Russian).

Tenson, J. 1995. Phytoplankton of Pärnu Bay. In Ecosystem of the Gulf of Riga between 1920 and 1990 (Ojaveer, E., ed.), pp. 105-126. Estonian Academy Publishers, Tallinn.

Tenson, J. \& Kaup, E. 1978. Comparative determination of photosynthesis under the ice with two oxygen methods. In Problems of the Baltic Sea, pp. 65-71. Tallinn (in Russian).

TGM-3M. 1963-1970. Tables of Deep-sea Hydrological and Hydrochemical Observations. Board of Hydrometeorological Service of Latvian SSR, Riga (in Russian).

Tirzitis, U. D. 1980. Stickleback (Gasterosteus aculeatus) behaviour in the zone of action of white and monochromatic artificial light. Rybokhozyajstvennye issledovaniya v bassejne Baltijskogo morya, 15, 160-170 (in Russian).

Trauberga, E. F. 1970. Feeding characteristics of juvenile herring in the Gulf of Riga in 1965-1967. Rybokhozyajstvennye issledovaniya v bassejne Baltijskogo morya, 7, 52-65 (in Russian).

Trei, T. 1976. Brown and Red Algae in the Coastal Waters of Western Estonia. Zvaigzne, Riga (in Russian).

Toompuu, A. \& Elken, J. 1995. Hydrographic studies within the Gulf of Riga project, 1993-1994. EMI Rep. Ser., 1. Eesti Mereinstituut, Tallinn.

Urtans, E. 1990. Feeding characteristics of smelt (Osmerus eperlanus eperlanus L.) and eelpout (Zoarces viviparus L.) in the Gulf of Riga. Fisch. Forsch., 28, 34-38 (in Russian).

Urtans, E. 1992. Feeding daily rhythm of eelpout (Zoarces viviparus (L.)) in the Gulf of Riga. ICES C.M. 1992/J:28.

Vainu, E.-M. 1964. Riia lahe ogalikust. LUS-i aastaraamat, 56, 147-156.

Vitinsh, M. J. 1988. Young flounder and turbot surveys with the beach seine in the eastern Baltic in 1986 and 1987. ICES C.M. 1988/J:8.

Vitinsh, M., Gaumiga, R. \& Mitans, A. 2001. History of Latvian fisheries research. Proc. Estonian Acad. Sci. Biol. Ecol., 50, 85-109.

Wasmund, N., Andrushaitis, A., Lysiak-Pastuzak, E., Müller-Karulis, B., Nausch, G., Neumann, T., Ojaveer, H., Olenina, I., Postel, L. \& Witek, Z. 2001. Trophic status of the south-eastern Baltic Sea: a comparison of coastal and open areas. Estuarine Coastal Shelf Sci., 56, 849-864.

Yurkovskij, A. K. \& Bramane, A. E. 1977. Annual cycle of changes of biohydrochemical parameters in the Gulf of Riga (1974-1975): phytoplankton pigments. Rybokhozyajstvennye issledovaniya $v$ bassejne Baltijskogo morya, 13, 54-69 (in Russian).

Yurkovskij, A. K., Grotane, B. Ya. \& Krumberga, I. O. 1977. Annual cycle of changes of biohydrochemical parameters in the Gulf of Riga (1974-1975): phosphorus, salt nitrogen, organic carbon. Rybokhozyajstvennye issledovaniya v bassejne Baltijskogo morya, 13, 39-53 (in Russian).

Yurkovskis, A. \& Mazmachs, M. 1996. Gulf of Riga. Hydrochemistry. Third Periodic Assessment of the State of the Marine Environment of the Baltic Sea, 1989-1993. Background document. Baltic Sea Environ. Proc., No. 64. B, 64-66. Helsinki.

Yurkovskis, A., Kostrichkina, E. \& Ikauniece, A. 1999. Seasonal succession and growth in the plankton communities of the Gulf of Riga in relation to long-term nutrient dynamics. Hydrobiologia, 393, 83-94.

Zakharchenko, N. Ye. 1962. Water transparency of the Gulf of Riga. Sb. Rabot RGMO, 1, 830-102 (in Russian).

Zakharchenko, N. Ye. 1982. Hydrological aspects of oxygen-deficiency zone formation in bottom layer of the Gulf of Riga. Sb. Rabot RGMO, 19, 34-43 (in Russian).

Zarins, E. \& Ozolins, J. 1935. Untersuchungen über Zuzammensetzung des Meerwassers im Rigaschen Meerbusen und an der Lettländischen Küste des Baltischen Meeres. J. Conseil Int. pour l'Explor. Mer., 10, 275-301.

Zute, S. 1973. Primary production and decomposition of organic matter in the southern Gulf of Riga. Izv. AN Latv. SSR, 1 (306), 32-35 (in Russian). 


\title{
Liivi lahe ökosüsteemi uuringute ajalugu
}

\author{
Henn Ojaveer ja Andris Andrushaitis
}

Eluta keskkonnaga võrreldes on Liivi lahe elustiku vaatluste ajalugu üle kahe sajandi lühem: kui esimesed andmed Liivi lahe elustiku kohta pärinevad 18. sajandi keskpaigast, siis eluta keskkonna andmestik - jäälagunemine Riia sadamas - ulatub 16. sajandi esimesse poolde. Esimene teaduslik merereis, Vene Balti-ekspeditsioon, mille käigus koguti esmased andmed planktoni kohta, toimus aastatel 1908-1909. Süstemaatilisi, kuid peamiselt kirjeldavat laadi mereuuringuid viidi läbi nii lahe põhja- kui ka lõunaosas 1920. aastate keskpaigast alates. Nende käigus mõõdeti mitmeid hüdroloogilisi ja hüdrokeemilisi parameetreid ning koguti kvalitatiivseid ja kvantitatiivseid andmeid planktoni, põhjaloomastiku ja kalade kohta. Peale Teist maailmasõda algasid pikaajalised süstemaatilised ökosüsteemsed uuringud olulise rõhuasetusega töönduslikele kalavarudele. Vaatamata mitmete oluliste uuringute jätkumisele ja osalisele laienemisele 1990. aastatel, on mõned pikaajalised väärtuslikud andmeread katkenud. 